3 2 Version Number

\title{
Video Ethnography and Critical Research for More Democratic Urbanization: The Case of Milan's Chinatown
}

\author{
Lidia Katia C. Manzo
}

This article reflects on the notion of urban democracy through a video-ethnographic study of the conflicts that followed the 2007 riots in Milan's Chinese neighborhood. I explore how the theoretical and methodological union of critical urban ethnographies with social documentary techniques can contribute to praxis for more democratic urbanization. Through selected video-ethnographic vignettes, I discuss how such an approach involves issues of ethics, voice, form and politics. The documentary exposes the material effects of inequality and domination in a unique and vivid manner; it also offers alternatives and encourages the ethnographer to assume a clear position in intervening on hegemonic practices. The conclusion explains how the production and consumption of such video-ethnographies affect the social, moral and, most importantly, political perception of a particular urban setting.

\section{PROLOGUE: CHINATOWN CALLING}

Between 2007 and 2009 I did ethnographic research on the implications of the riot that broke out within the Chinese community in Milan in April 2007 [Figure 1] and other conflicts that ensued related to local urban transformation. This research informed my final project for my M.A. program in Political and Social Communication at the University of Milan [Manzo 2009]. During the early stages of participant observation and conversations with research contacts I began thinking about how to create a project that would extend beyond the scope of a mere written thesis. Despite the fact that I planned to focus on the incumbent gentrification of this multiethnic neighborhood, I started to consider the possibility of doing ethnography also to "reach out" to the public and share my insights. I was motivated to do so by the exacerbation of stereotypes and

LIDIA KATIA C. MANZO is an urban ethnographer and postdoctoral research fellow in the Geography Department at the Maynooth Univrsity. Her urban and visual work examines how the everyday co-productions of space and identity support or inhibit social, spatial and economic justice, as discussed in her most recent edited volume, Culture and Visual Forms of Power: Experiencing Contemporary Spaces of Resistance [Common Ground, 2015]. She is now doing research on urban regeneration and welfare-state transformations in Dublin. E-mail: lidia. manzo@gmail.com or lidia.manzo@nuim.ie; website: www.lidiakcmanzo.com

Color versions of one or more of the figures in the article can be found online at www. tandfonline.com/gvan. 


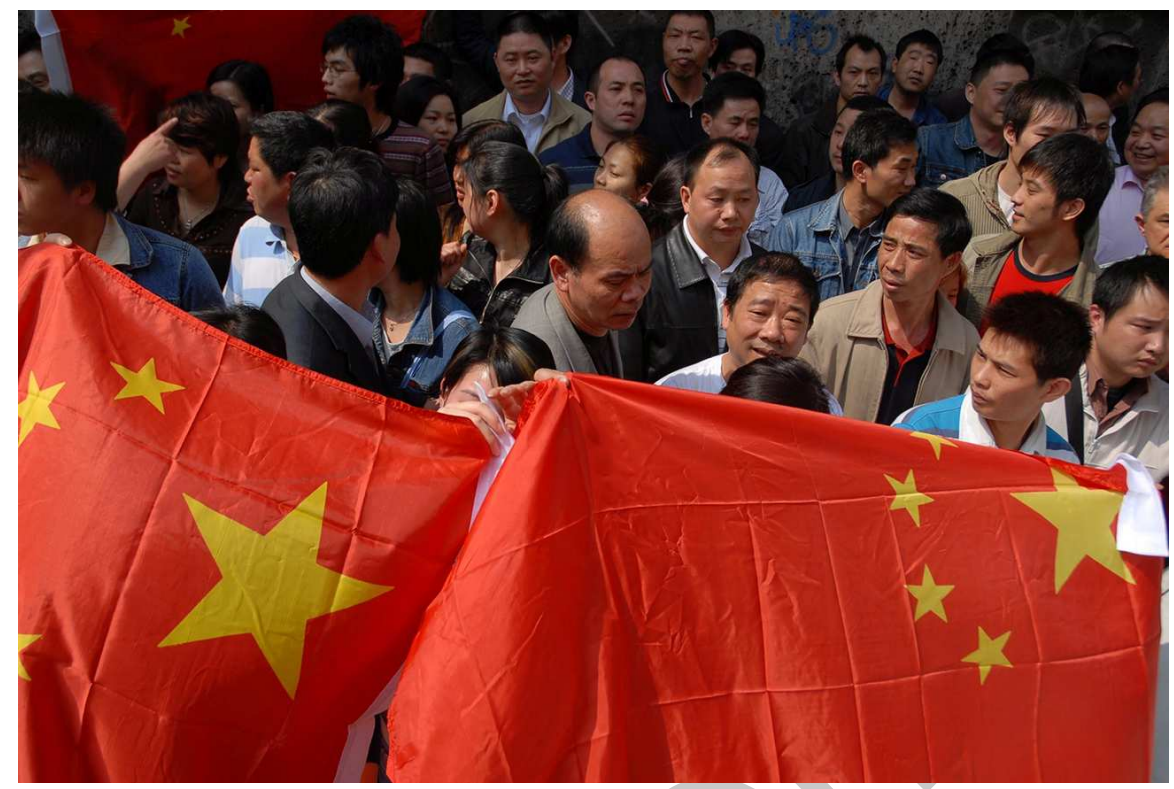

Figure 1 The urban conflict in Via Paolo Sarpi. On April 12 2007, 300 Chinese residents and entrepreneurs reacted violently against a provision of municipal security forces, causing the riot along via Paolo Sarpi and intersecting streets. (Photo (c) the author)

prejudice against the Chinese community from the media and local politicians ${ }^{1}$ in Milan. Members of the community who lived, worked, or just engaged in the consumption of culture and goods in Chinatown cooperated with me to voice their side of the story. The applied ethnography project, of which the videodocumentary $^{2}$ was a part, led to an eight-year-long research period, from 2007 to 2015 .

\section{INTRODUCTION: THE VIDEO-ETHNORAPHIC PROJECT}

Video ethnography applied in urban research is an interdisciplinary practice, drawing upon a wide range of approaches to represent urban spaces. Such practices may be distinctly described as documentary, fine art, design, architecture, ethnography, or social science-based, depending on their historical traditions and contexts. Despite their distinct forms, they are all connected by an intention to clarify, research, and interact with urban life through lens-based media or other forms of visualization [MacDougall 2006; Mitchell 2011; Nathansohn and Zuev 2013; Rose 2001]. In both literature and practice, video ethnography is emerging as a planning tool in designing action research projects [Sandercock and Attili 2010, 2014].

In this work, I pose a series of questions that problematize current debates about digital ethnographic intervention techniques. It is tempting to imagine alternative knowledge about the urban sphere that may lead to projects which promote socioeconomically even growth, which would be optimal. How can we achieve more egalitarian neighborhoods, considering that stakeholders have 
conflicting interests and some will always have more financial and cultural capital than others [Harvey 2006]?

Drawing on several years of field research on the multi-ethnic neighborhood of Via Paolo Sarpi-what is referred to colloquially as Milan's Chinatown-I explore how a union of video ethnography with critical research contributes to praxis and more democratic urbanization beyond theoretical assumptions. I sustain this argument because, in many cases, the voices of the "urban powerless" are often misrepresented by the prejudicial narratives provided by both the media and government institutions. Revanchist tactics [Smith 1996] have defined the rhetorical paradigm "against minorities," and inform local urban renewal policies in multiethnic neighborhoods in Milan [Manzo 2012; Verga 2016]. "Global capitalism all but guarantees that there will be constant pressure on these neighborhoods," Shortell and Aderer argue about other Chinatowns in the world. They stress that collective identity shows, even in the face of this pressure, "some of the ways that meaning-making, and therefore, communitybuilding (and sustaining) is embedded in urban public space" [2014: 127].

Two objectives came out of this research endeavor. The first objective was to describe how the video-ethnographic project was created in the study community; the second was to show how this project succeeded in promoting more democratic urbanization. I argue that video ethnographies reveal the material effects of inequality and domination in a unique and vivid manner, uncovering how "power mechanisms" [Foucault 1983] are exercised in relation to place, people and practices. They also offer alternative meanings and encourage the ethnographer to assume a clear position in intervening on hegemonic practices [Carspecken and Apple 1992; Fine 1994; Madison 2005]. This article will discuss how ethnographic video engages with issues of ethics, voice, form and politics. The conclusion explains that the production and consumption of such documentaries channel the engagement of multiple stakeholders, both powerful and powerless, to spread awareness among social scientists, the public, and community members of a neighborhood in conflict.

\section{VIDEO ETHNOGRAPHY, MULTIPLE VOICING, AND COMMUNITY EMPOWERMENT AS AN APPLIED FRAMEWORK}

Video ethnography is approached from a specific angle in this work: as a collective thinking process, intended to be the result of the cooperative interactions between the ethnographer and social actors that would not exist if not for the camera. ${ }^{3}$ This participatory mode of research constructs worlds of meaning based on interviewees' knowledge practices, and has the potential to transform the way authors and audiences interpret an issue through documentary techniques [Banks 2001; MacDougall 2006; Pink 2007; Strandvad 2013]. The quest for representation becomes constitutive of the same process of knowledge-making [Colombo 2015], and it thus deals with issues of validity. In an effort to resolve this "crisis of representation" [Lassiter 2005: 48], video ethnographers can usefully "borrow" some of the richest and most innovative reflections available in the domain of qualitative inquiry [Denzin and Lincoln 1994]. According to Gergen and Gergen 
[2003], perhaps the most promising developments are the conceptual and methodological explorations of polyvocality to empower research. Their importance derives partly from "the way they challenge the traditional binary between research and representation" [ibid.: 1027] and partly from their potential to expand "the range of communities in which the work can stimulate dialogue" [ibid.: 1030].

A polyvocal approach is especially promising in its capacity to provide a rich array of interpretations, particularly in matters that involve a range of conflicting perspectives. Within this research architecture the ethnographer can serve as "director" of those interpretive activities and take a position on the stylized representation of both audio and visual contents. In other words the ethnographer can use literary styling signals, in either the video editing or the written report, to signal to the audience that "the account does not function as a map of the world (and indeed, that the mapping metaphor is flawed), but as an interpretive activity addressed to a community of interlocutors" [ibid.: 1029]. Those signals may take the form of fiction, poetry, autobiographical invention and even performance [Conquergood 1989; Denzin 2003]. In this way participants and the researcher share power and control over the research, and participants feel responsible for the dissemination of the final outcome.

Positive participation and community empowerment are not an easy research feat, however. This is particularly true in conflicting communities, where the ethnographer cooperates with various social groups to reduce difference and foster understanding. ${ }^{4}$ The longitudinal work conducted by Elijah Anderson [1990, 1999, 2011] on both marginalized low-income African-American groups and mainstream middle-upper Whites in Chicago and Philadelphia shows how engaging in dialogue requires of the ethnographer "a strong desire, at times with a degree of courage." Desire and courage are needed to represent informants' worlds "accurately" for readers, "who may have such strong preconceptions that no amount of ethnographic evidence to the contrary will be convincing" [Anderson 2002: 1538]. Community empowerment is a result of ethnographic work. An inherent challenge of ethnography comes in providing truthful representations as the ethnographic work continues to unfold and as the audience's awareness grows "with the consumption of that work" [ibid.: 1548].

The value of this theoretical and methodological framework lies in its potential to be applied in the field of critical urban research, to shed light on the system of power relations behind processes of uneven development [Harvey 1982]. Consequently politically or morally motivated ethnographers [Manzo 2016a] may look into ways to intervene "in the form of changing how their audience perceives an issue or bringing to the fore a controversial issue" [Pink 2011: 442]. Ethnographic video documentaries make visible what was previously incomprehensible. Accordingly to Panagia [2009], this act of power is able to change the way we view ourselves and others, as well as how we view events, objects or processes. In "rendering perceptible" the micro-operations of power, the researcher not only enhances his or her understanding-increasing meaning and significance through video ethnography-but also promotes a politics of resistance. Crinall calls for the visual emergence of spatial political actions, to be understood as "a site of resistance occurring at the social level, where ideological contestation 
is publicly expressed with the goal of bringing about change in the practices, values and beliefs" [2015: 23-24]. If ethnographers can be seen as "a kind of vessel" [Anderson 2002: 1538] or "conduits for power" [Bourgois and Schonberg 2009: 13], then it needs to be acknowledged that video ethnography can be a channel through which political action can spur resistance.

The following sections introduce the case study of Milan's Chinatown and discuss how video ethnography can contribute to praxis for more democratic urbanization, particularly in socially, ethnically and politically charged communities.

\section{VIA PAOLO SARPI: MILAN'S CHINATOWN}

The first Chinese immigrants who settled in Milan in the late 1920s came from the coastal province of Zhejiang in eastern China. This small group of men decided that the metropolis was the ideal place to "make good fortune." Milan seemed to be a relatively promising city, and throughout the 1930s it became one of the destinations for Chinese migrants to Europe [Figure 2, a photo of one of the pioneers of Chinese settlement in Milan]. This first community settled in Canonica-Sarpi, a semi-central neighborhood on the northwest border with Parco Sempione (the main city park). It was a working-class district with boutiques where housing was inexpensive and composed of a growing number of Italian migrants. Via Sarpi became the spine of the neighborhood's commerce, along which Case a Pigione houses with internal courtyards and ground floor commercial or artisan shops were erected.

During the 1980s Milan's economy experienced tertiarization, as a new population of high-profile managers and professionals was attracted from other

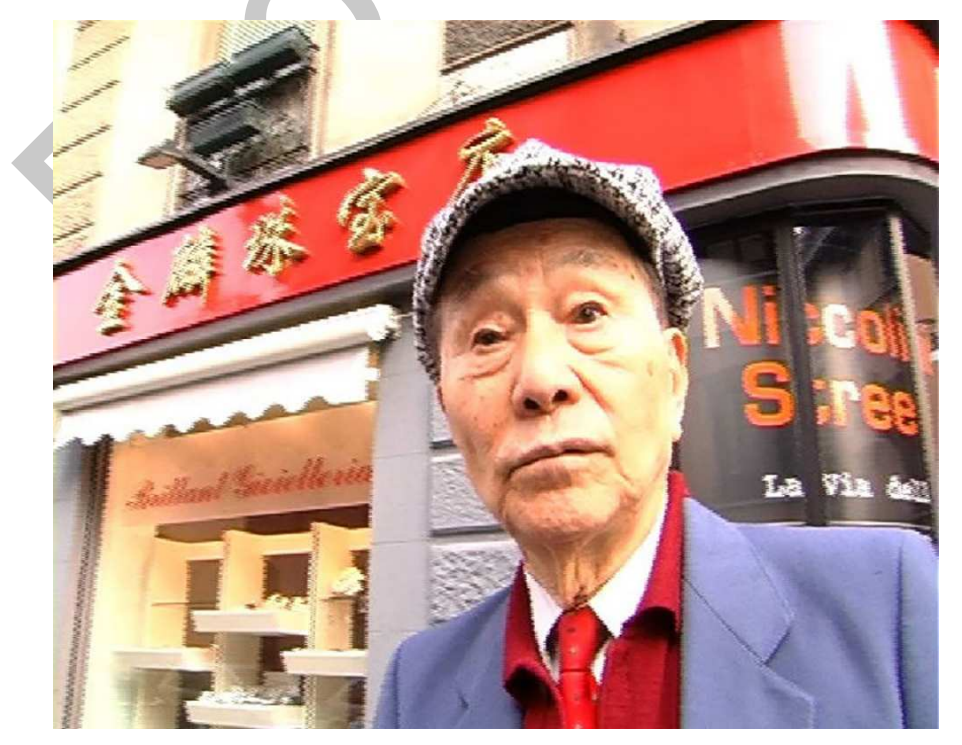

Figure 2 Video still of Sang Wang-better known as "Zio [uncle] Romanino"-one of the pioneers of Chinese settlement in Milan and a point of reference for the Milan Chinatown Community, recorded on Via Paolo Sarpi. (RT=4:04). (Photo (C) the author, 2009) 
parts of Italy and abroad. This in turn resulted in the progressive exclusion of the lower classes from central parts of the city, due particularly to the rise in property values in historic areas. In the 1990s, after the simplification of the new law on commerce, there was a gradual substitution of small stores in the neighborhood with retail and wholesale Chinese-owned operations [Manzo 2016b]. Today the neighborhood is virtually closed to newcomers: real estate is sold and leased at "the price of gold," and there is no room for the form of subsistence entrepreneurship that characterized the first Chinese immigrants here:

"Chinatown" has become the neighborhood window display of those who "have made it," it is the ideal place to open innovative and "ethnically dedicated" commercial activities, where to locate meeting places (bars, restaurants, night clubs frequented by Chinese) and representative activities (headquarters of associations). [Mancini and Cologna 2000: 71]

In Milan's Chinatown, despite a multi-ethnic mix of entrepreneurs and users, the residents today are almost all Italian. This homogeneous ethnic composition is the main point of tension within the local community [Novak 2002]. There is a constant equilibrium between the commercial needs of retailers and wholesalers and the lifestyle and consumer habits of residents and visitors. It is a social model under which "intolerance, exasperation, and exhaustion boil. From both sides, Italian and Chinese." The urban riot of 2007 can be said to be the result of the unease felt by Chinese entrepreneurs. Italian residents complained incessantly about the Chinese merchants' practices. Furthermore, the local government, which had criminalized Chinese wholesale as the symbol of illegality and insecurity during the previous Mayor Moratti's term, was issuing fines to Chinese wholesalers and retailers. Hiding behind the presumed interest of public order, the "zero tolerance" municipal politics created new obstacles for Chinese wholesale activity in 2008. The political force against these activities was so strong that the main street, via Sarpi, was finally closed for over a year (2010-11) in order to pedestrianize the area. The project had been declared as a last resort politically to discourage the development of Chinese commerce and promote the speculative renewal of the Sarpi neighborhood.

Milan's Chinatown is the multi-ethnic neighborhood on Via Paolo Sarpi where streets, the international flow of Chinese goods, and the daily routines of elderly Italians and local families intersect. It is also the setting of the Chinese riot that broke out in 2007. Thoughts, memories, desires and fears of ordinary people living, using and working in the neighborhood are in testimonials of residents, store owners, key informants and city rulers. They provide perceptions and feelings that expose the effect of the stigmatized rhetoric produced by "the powerful" in the name of speculative intents. Pursuing social analysis, advocacy, and provocation with ironic effectiveness, A-way from Paolo Sarpi paints the Milan Chinatown's conflict as a political economy question, moving us to inner debate and realization. [Synopsis for A-way from Paolo Sarpi; (C) the author, 2009]

The next section of this paper describes how the production and consumption of the video ethnographic project were created with the aim of engaging multiple stakeholders and raising awareness among members of Milan's Chinatown community, other social scientists, and the public. 


\section{VIDEO ETHNOGRAPHY AS A CHANNEL FOR MORE DEMOCRATIC URBANIZATION}

The ethnographic video documentary A-way from Paolo Sarpi attempts to explain how two urban populations, the Chinese entrepreneurs and the Italian residents and storeowners, perceived the neighborhood conflict and negotiated the terms of public space on its main street, Via Paolo Sarpi. The following questions were addressed as part of the project: Which tensions-sociocultural, political, and economic - caused the 2007 riots in via Paolo Sarpi? To what extent did urban policies provoke the conflict? and What were the perceptions of all social actors of the riot's effects on the community? I developed a video ethnographic project which included participant observation and detailed interviews in order to answer these questions. Audiovisual data were collected from various parts of the neighborhood in both public (streets and sidewalks) and semi-public spaces (cafés, restaurants, Italian and Chinese shops, and the local Catholic Church). A-way from Paolo Sarpi offers a "thick description" [Geertz 1973] of public life in Milan's Chinatown. The documentary includes Italian residents' and Chinese entrepreneurs' firsthand accounts of life in the community and everything they wished to share about the urban conflict and new government policies that had emerged before and after the riot. City Councilors and key informants were interviewed too, and they form part of the video production.

\section{The Production: Engaging with Multiple Voices}

When I began ethnographic research on this Chinatown as an undergraduate student, I had difficulty finding research participants. Few people, whether Italian or Chinese, wanted to share thoughts about their neighborhood with me. Residents and storeowners were wary because, after the riot, many journalists had swooped down on via Paolo Sarpi to interview them. The level of tension between the different social groups was so high at that time that the idea of a participatory video project was nonsensical. I did believe it was possible to develop a form of collaboration with different community leaders, however. From my early participant observation and research I had developed a network of contacts, which helped give me access to those groups. The gatekeepers were fundamental in negotiating the necessary trust with the community. Some of them were easier to meet, like the local resident group representatives or the Italian storeowners. With regard to the politicians, I took advantage of my professional network and was able to get in touch with friends of mine who worked in the City press office (the good reputation of the researcher is an indispensable asset). One of the leaders of the Chinese community had a very difficult time accepting me. In fact, I literally followed the president of the second-generation Chinese association Associna for quite some time, attending public meetings and cultural events.

Later on, I met Jianyi in via Sarpi. We walked toward the little square in Santissima Trinità and sat down on a bench, observed the kids coming out of the kindergarten, and talked 
for Jianyi, choosing to participate in my video project meant much more than providing a better understanding of his community. He wanted to help me understand the basic characteristics of the Chinese culture, like guanxi (relation) and mianzi (prestige/face), but he had other reasons for participating as well. He wanted to share his struggle in being a first-generation Italian resident who had been living in Italy for 27 years without having the legal opportunity to become a citizen, vote, or simply be represented in local public discussions. He wanted Italians to understand this perspective as well. [Fieldnote, November 21, 2008]

The result of his cooperation was a representative Chinese voice in the video ethnography. The distinct voices of my gatekeepers and informants enriched my understanding of the reasons for the tension, instead of diluting or thinning the level of discourse [Lassiter 2005]. They helped me identify cries for social justice more clearly than I could have done by merely delving into more theoretical questions.

The filming style was motivated by practicality; it was not a stylistic choice. The same can be said for the sound, which almost always includes background noises. I made a conscious choice to use the "raw visual material" that I could collect with my own equipment. With this in mind I decided to record the interviews myself using a non-professional camera, and occasionally asked friends of mine to record those interviews in which I preferred to have direct dialogue with the participant, rather than speaking "through" a video camera. In the end, the handheld shots were more appropriate for the subject matter because the camera movements perhaps reflected the dynamic urbanity of the neighborhood. The impression of urban authenticity conveyed through the video was happenstance; its powerful meaning began with the raw cinematic image and the appearance of movement.

While the video interviews with the research participants were planned, the recordings of the neighborhood's public spaces were not. Frankly I have never experienced any particular problem when asking passers-by to be video-recorded and sign the appropriate release. In my experience, young Chinese adults were the most willing to show off their new fancy-branded shoes or bags in front of the camera, curious to know more about the video project, and likely to suggest chatting over coffee. Elderly Italian residents were much more reserved. Video ethnographic practice helped me record evidence that disproved stereotypes of the "silent Chinese people" who "never leave their laboratories," and, most importantly, that "don't speak Italian!" The Chinese interviewees spoke perfect Italian, with a typical Milanese accent. My first recording on the main street, for instance, was unforgettable [Figure 3]:

I was just showing via Paolo Sarpi to my camera assistant when I saw three incredibly fashionable Chinese guys walking toward us on the sidewalk. "They are so cool ... I can't miss this scene," I thought. So I asked the cameraman to start shooting, and while they walked toward us we began to record, walking backwards ... crazy, from the main street to a narrow side street, keeping my right hand behind the camera operator to help her walk safely. The guys are interesting characters, with a haughty smile ... trendy haircuts ... one of them has long blonde wild hair all over around his head, others wear leather jackets, have a gallant move... Ah-ha, unbelievable, they bring us where they 


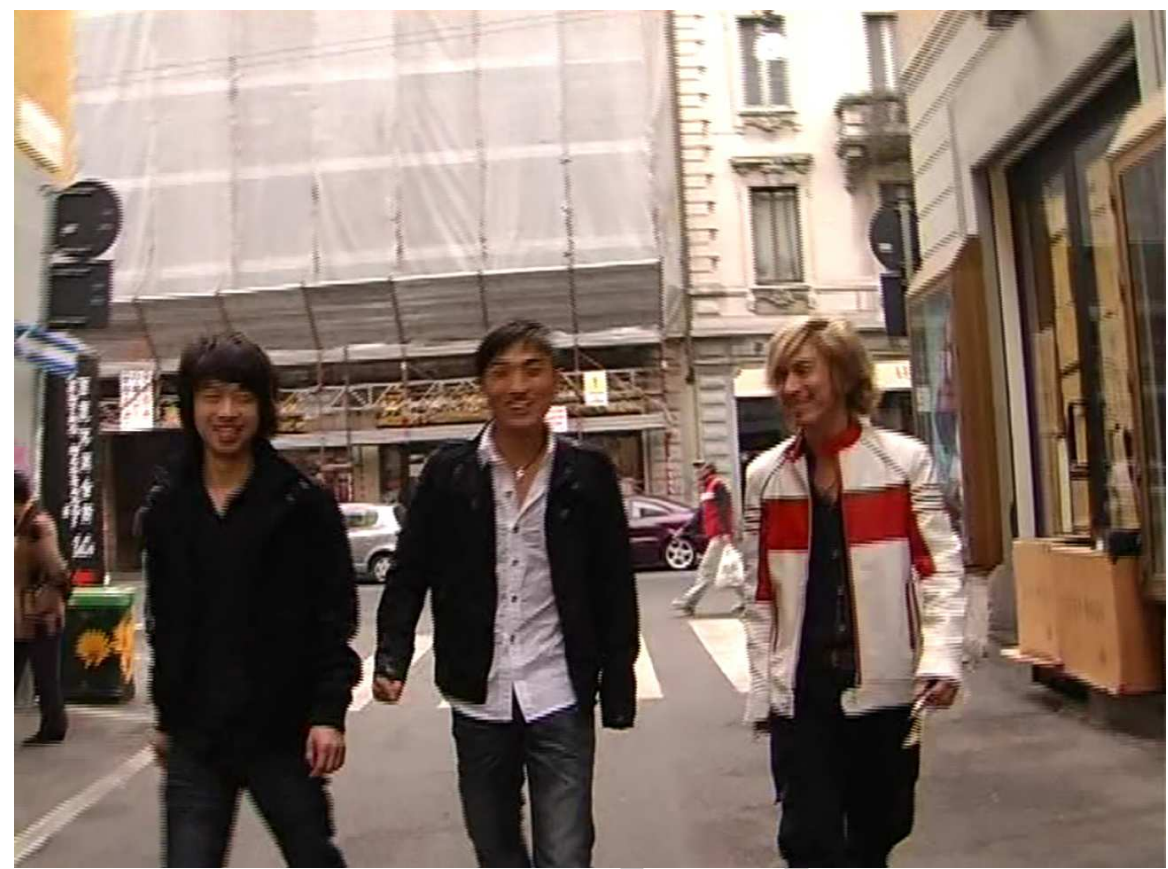

Figure 3 Baidu Chinese hairdressers in via Paolo Sarpi, video still $(R T=18: 10)$. Chinese hairdressers have been at the center of controversy in Milan for quite some time due to their ability to attract customers with very low prices. Numerous popular prejudicial narratives went around describing these shops as covers for prostitution or other illegal activities or for the use of harmful/non-controlled products, such as hair dye which "comes from China." In the video, Baidu is shown as an innovative beauty salon for the type of cuts (Asian hair styles), the design of the store (with flat screens that broadcast manga on the walls), and for the trendiness of its hairstylists. (Photo (C) the author, 2009)

work: Baidu, one of the local Chinese hairdressers of the neighborhood! And I start to wonder: where is that Chinese community that is depicted as hidden and terribly dangerous? [Fieldnote, October 25, 2008]

Via Paolo Sarpi presented to me an innovative character, a cosmopolitan ethos, and a transnational lifestyle, particularly due to the young, first- and secondgeneration Italians of Chinese descent. They display how multiple hybrid identities do not make them feel as "linked" to a specific territory. This is also one of the main reasons why the local government has been committed to opposing this hybridization process [Manzo 2011] with policies aimed at normalizing ethnic groups to the dominant social order. Indeed, that scene gave me the strength to produce the video.

The production phase of A-way from Paolo Sarpi clearly raises the issue of "voice," the form in which the argument is logically organized and (re)presented. Since the different social groups were not willing to work together at that time, I edited the work myself. A polyvocal text was produced relying on an interview-storytelling structure, avoiding the voice-over commentary to give the documentary a testimonial and compelling quality. I made my voice as 
author/ethnographer emerge from the careful texture of the selected interview material, and adopted a narrative strategy that brought together people and organizations, to adopt an ethical approach as a responsible advocate [Banerjea 2014]. This video-ethnographic platform proved to boost awareness and alleviate rising authority/power issues tied to the social construction of knowledge. To explain this, I organized the story into three parts: (1) introduction of the urban setting, description of the social actors, and definition of the conflict in the Chinatown, (2) the highlighting of socio-economic implications by showing the characters' engagement in social struggles, and (3) the climax, or final confrontation, which also offers an interpretation of the whole work [Rabiger 2009]. The "dramatic curve" can be considered as an arc of changing pressures used to interpret the unfolding cultural scenes during recording [Figure 4].

Building upon the legacy of participatory documentary, theater and social critique, I decided to expose interplay between antagonism and juxtaposition to highlight the existing conflict, with the aim of understanding and explaining the tension in this urban space. This narrative of the video builds on a mosaic format [White, Makris and Lizaire-Duff 2011] represented by the subjective perspectives of 23 participants ${ }^{5}$ involved in this political and social discontent. The following interview excerpts create a dialogue between local resident group representatives (Pierfranco Lionetto), the Chinese youth (Jianyi Lin), the urban policy councilor (Carlo Masseroli), and a professional urban planner (Christian Novak).

$(R T=6: 36)$ Loading goods and everyday Chinatown neighborhood practices. Pierfranco Lionetto, voice only:

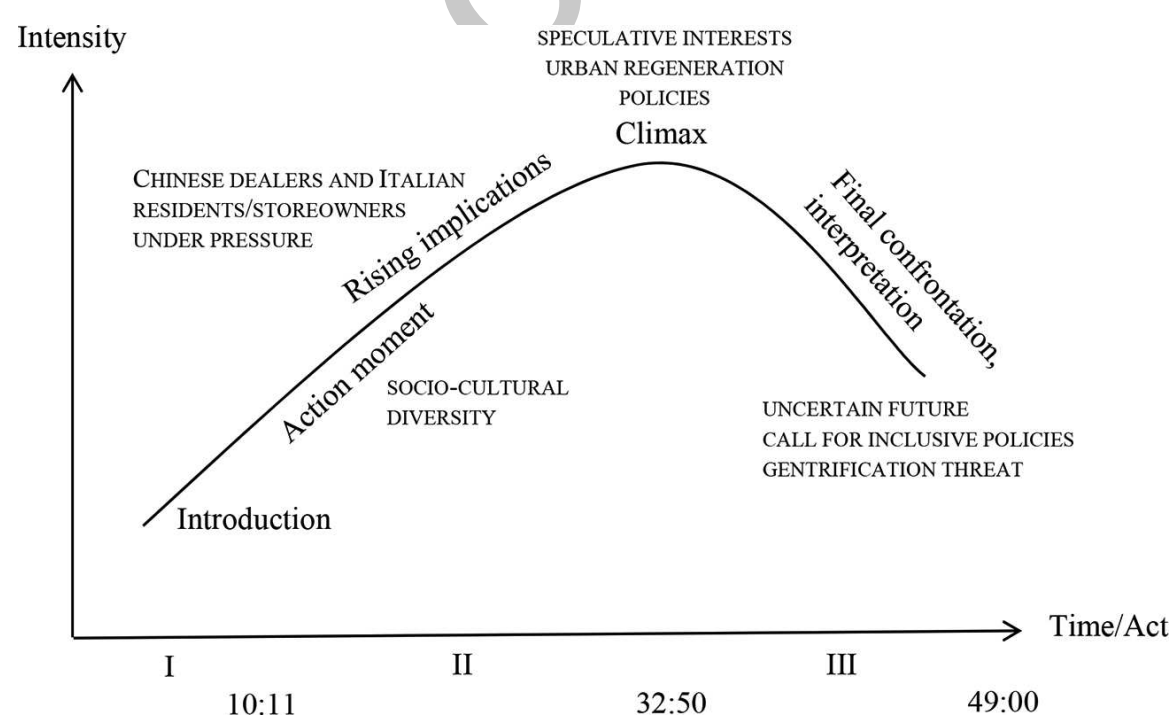

Figure 4 The arc of changing pressures that represents the narrative structure of A-way from Paolo Sarpi in three acts: I: the rising spatial implications of sociocultural diversity; II: the intersection of Chinese entrepreneurs and Italian residents and storeowners with the speculative urban regeneration policies of the local government; and III: the final confrontation of the social actors who participated in the video ethnography and their perceptions of their community's uncertain future. 
Everything began with the first Chinese wholesaler settlements on via Bramante. That street already had problems, as the tram rails didn't allow parking there. There were some shops that had been shut for awhile and some warehouses. In 1999, the Chinese suddenly bought all the shops and changed them into wholesale warehouses. In that period, big trucks stopped right in the middle of the road every day to unload goods.

Pierfranco Lionetto on camera:

These unclear signs of change created an emergency situation in the neighborhood, and that's when people got together. A 600-person assembly took place. Mayor Moratti participated, along with Mr. De Corato and the Municipal Police chief, Mr. Bezzon.

Chinese dealers and local police on via Paolo Sarpi. Pierfranco Lionetto, voice only:

It lasted from 9:00 p.m. until 12:30 a.m. During that time, frustration, exasperation and anger were expressed toward the situation and against local governance.

Carlo Masseroli on camera:

The pedestrianization of via Paolo Sarpi was a response to one of the most important commercial parts of Milan being quietly invaded by the Chinese community. The problem lies in the fact that a street of such dimensions, located in the city center, is totally inadequate to serve as a freight logistics center.

Christian Novak on camera:

The neighborhood doesn't have any public spaces. It is mainly made up of densely packed roads, and the only large public space is via Paolo Sarpi,

A child plays with a little car on the sidewalk. Christian Novak, voice only:

which has always been a commercial street of the neighborhood and a historical meeting point, recognized by everyone as such.

$(R T=9: 18)$ Jianyi Lin on camera:

The term Chinatown is a bit inappropriate.

The Milan's Chinatown Neighborhood (video images). Jianyi Lin, voice only:

When you talk about Chinatown, the large neighborhoods of Chinese settlement come to mind, where all the shops, the residents, and people on the streets are Chinese. Instead, in via Paolo Sarpi, everyone knows that 95 percent of the resident population is Italian, with the minority being Chinese.

Christian Novak on camera:

The separation between the ground floor and the highest floors is what creates the real problem of cohabitation. The former is almost entirely Chinese, in terms of use and attendance, and the latter is almost completely Italian. This wouldn't have occurred if our Chinatown had developed as the ones in the United States did, where most of the residents, traders and users are Chinese.

The video is intercut with images shot in the neighborhood that tell a different story from the biased one typically represented in the local media and political rhetoric. At its heart is a set of everyday practices and behavior that reflect a search for community. Community drives public life and contradictions within Milan's Chinatown. The distinct rhythm of Chinese retail and wholesale stores, with their fervid loading and unloading of goods for customers coming from all over Milan and storefronts full of cardboard boxes, provides a stark contrast with old, traditional Italian mom-and-pop shops, which show a meticulous attention for detail deeply rooted in Italian culture. Elderly residents' daily strolls on the sidewalks of via Paolo Sarpi intersect with those of Chinese youth who work or relax in the neighborhood. Simultaneously both Italian and Chinese mothers walk their children to school, go to Chinese hairdressers, shop at the local butcher, or meet at the parish hall with other members of the community. Young Italian adults also flood 
these street beginning at 6:00 p.m. for the aperitivo at the local enoteca; ${ }^{6}$ they are attracted by the many Asian food markets and cheap Chinese stores.

The visual display of via Sarpi's lively and colorful public life shows the inclusive hybridity of everyday practices and places [Manzo 2011], enabling the realization of the revanchist rhetoric hidden behind the narratives of local politicians. The following script excerpts depict these contradictions, with the Deputy Mayor Riccardo De Corato and the representative of AssoCina (the secondgeneration-Italian Chinese association) speaking "in dialogue" on the matter.

(RT = 30:19). Riccardo De Corato on camera:

Every day I work with 150 ethnic groups that are present in our city. The one I am most concerned with are the Chinese because they work hard. The others, some are idlers and a few are like us Europeans ... the Arabs, there are like 80,000 Muslims ... but still, can be managed. With the Chinese you can't do anything ... I even know some of them, and I respect them. I think to myself: 'shit ... these people work hard. What can you do to them?'

Jianyi Lin on camera:

The Chinese businessmen of via Paolo Sarpi took over Italian companies, paying a price much higher than market value.

The Milan's Chinatown Neighborhood (video images). Jianyi Lin, voice only:

They had this opportunity because, in the 1990s, anyone could get a commercial license, and it became typical for Chinese investors to open their businesses there. The discourse that kind of blew up last year is connected to exactly this: the fact that all of the Chinese wholesalers started to get fined!

Jianyi Lin on camera:

These series of fines and prohibitions came overnight; all of the Chinese businessmen found themselves facing difficulties that they hadn't in the beginning.

Riccardo De Corato on camera:

Yes, the hand-carts, we are making war against the hand-carts, but it isn't the handcarts. The problem is much bigger!

Milan's Chinatown Neighborhood (video images). Jianyi Lin, voice only:

Italian distributors, for example ... the ones that load and unload dairy products...

Jianyi Lin on camera:

... were completely ignored by the police even if they use hand-carts to go around

Chinese workers with their hand-carts. Jianyi Lin, voice only:

while the Chinese were systematically stopped and fined. This type of discrimination bothered people.

Jianyi Lin on camera:

When ethnic factors come into play with commercial interests, the risk that is created is very dangerous ... explosive!

Voice in video ethnography acquires the function of style in fiction films, but operates differently. This form of documentary testifies to the ethnographer's ethical stance, and serves as evidence of research reliability, stemming from the multiple voices of the community.

The Consumption: Enabling Awareness

Although the ethnographic video finally produced in 2009 was temporal and specific to the investigation of the Chinese riot of 2007, its consumption in various 
screenings and debates brought about more awareness that developed at different levels and involved different audiences. It has been screened many times in national and international academic contexts, as well as at communitybased meetings in Milan. The video ethnography actively assisted in a broader, grassroots social empowerment scheme, providing platforms from which "the struggle of others" could be known and heard [Manzo 2015].

At the community level, Jianyi, Pierfranco and the other representatives used the video for their own purposes to resist the state-led process of gentrification that the neighborhood is undergoing [Manzo 2016b], demanding sustainable planning interventions. On the basis of my successive six years of fieldwork I can say that the screening of the video during meetings and debates made the very same research participants evoke their own self-representations, experiential knowledge and feelings. The polyvocal approach highlighted the multiplicity of competing interests, contradictory values and varying orientations. The video channelled a democratic dialogue between members of Milan's Chinatown who could not find a point of unity. The video provided a chance for Italian residents to re-evaluate stereotypes of Chinese residents and workers, and challenged young Chinese entrepreneurs to work together to promote the sustainable development of the neighborhood against the speculative interests of the local government. More generally, the video succeeded in demonstrating the role of local government in the conflict and how the revanchist narratives drove the conflict in Milan's Chinatown.

\section{CONCLUSIONS: A PREMISE FOR SOCIAL CHANGE}

The most recent theoretical developments of ethnography, drawn from the overlay of feminist theory, participatory action and critical research, call for its constitutive potential to bring about positive change. In the above discussion the polyvocal documentary practice was understood to be a channel of resistance, where research participants collectively produced public space. In such a way, video ethnography can be part of a more democratic urbanization process, and can perhaps be a way to provide the audience with a new perspective, to encourage self-development and to spur social change.

As Benjamin states in his brilliant discussion [1970] of the role of "author as producer," the visual can truly subvert the mechanism of framing, as an apparatus "capable of making co-workers out of readers or spectators" [ibid.: 93]. Eco's theory of interpretive cooperation [1984] stresses the same essential role given to the reader (the audience) in the process of meaning negotiation carried out with the author (the ethnographer). It is in this light that video ethnographic practice "must function as a form of activism and transform readers/viewers into producers" [Sikand 2015: 52], blurring the line between the subject/social actors, the ethnographer and the audience. Representing others in ethnography, particularly in video ethnography, involves addressing this threefold relationship, which in turn determines the type of documentary the ethnographer will produce.

This article discussed concrete ways in which social scientists can support, strengthen and contribute to activist movements and social change striving 
toward progressive political action. If politics "begins with the rendering perceptible of that which has been previously insensible" [Panagia 2009: 153], when a light is shed on what was previously neglected or subjected to prejudice, then what was once invisible becomes "comprehended, explained to others, and can inform social interventions" [Pink 2011: 446]. Advocacy video-ethnographies, such as the one presented in this paper, aim to challenge our comprehension and ethics, calling for the researcher to respond and take responsible action in the field.

I believe that the creation of an ethnographic project that can be read, screened, discussed and distributed through a multiplicity of channels broadens the discussion of urban democracy. I learned an important lesson from representing the voices of my research informants through video-ethnography: their drive to collaborate for a more democratic urbanization "speaks aptly to our broader responsibilities as anthropologists to serve others through our work" [Lassiter 2015: 19], drawing ethnography closer to the studied communities.

\section{ACKNOWLEDGMENTS}

I thank Myna German for inviting me to discuss an earlier version of this work at the Dept. of Mass Communications of Delaware State University in November 2011; and would also like to thank the ISA Visual Sociology Working Group's board members, Regev Nathansohn, Elisabeth-Jane 'EJ' Milne and Valentina Anzoise, for the opportunity to present the documentary during the ISA Forum visual workshop held in Buenos Aires in July 2012. A-way from Paolo Sarpi was produced independently: I am especially indebted to Francesca Cogni, who assisted me with the editing in her lab. during the winter of 2009. I would also like to thank the anonymous reviewers for their comments which contributed greatly to improving the final version of this paper. And finally, I am grateful to all members of the Sarpi neighborhood in Milan for making this video project possible. The article is offered in memory of Zio Romanino.

\section{NOTES}

1. At the time of the Chinese conflict in 2007 the Milan local government was ruled by a right-wing alliance between the Berlusconi's Forza Italia party and Bossi's Lega Nord, well-known to be a xenophobic and anti-immigrant party.

2. A-way from Paolo Sarpi (in Italian Via $\mid$ da $\mid$ Paolo Sarpi), 2009; (c) the author, 49 minutes, 505 color, with English subtitles.

3. It is what Rouch and Morin defined as cinéma vérité [Rothman 2009].

4. In the context of urban research, the passion for raising awareness must be disciplined by a sense of regard for the relationship with the studied community. In other words, the ethical and moral commitment to not harm participants or exploit their vulnerabilities must be made.

5. Research participants agreed to appear in this video ethnography for research and political purposes, but not commercial ones. They also agreed not to be anonymous by giving their names to the author and consenting to their publication.

6. Wine bar.

\section{REFERENCES}

Anderson, Elijah

1990 Streetwise: Race, Class, and Change in an Urban Community. Chicago: University of Chicago Press. 
1999 Code of the Street: Decency, Violence, and the Moral Life of the Inner City. New York: W. W. Norton.

2002 The Ideologically Driven Critique. American Journal of Sociology, 107(6): 1533-1550.

2011 The Cosmopolitan Canopy: Race and Civility in Everyday Life. New York: W. W. Norton.

Banerjea, Niharika

2014 Critical Urban Collaborative Ethnographies: Articulating Community with Sappho for

Banks, Marcus Equality in Kolkata, India. Gender, Place and Culture, 22(8): 1058-1072.

2001 Visual Methods in Social Research. London: Sage Publications.

Benjamin, Walter

1970 The Author as Producer. New Left Review, 62 (July/Aug.): 83-96.

Bourgois, Philippe, and Jeffrey Schonberg

2009 Righteous Dopefiend. Berkeley and Los Angeles: University of California Press.

Carspecken, Phil Francis, and Michael Apple

1992 Critical Qualitative Research: Theory, Methodology, and Practice. In The Handbook of Qualitative Research in Education. Margaret D. LeCompte, Wendy L. Millroy and Judith Preissle, eds. Pp. 507-553. San Diego, CA: Academic Press,

Colombo, Enzo

2015 The Representations of Power and the Power of Representations. In Culture and Visual Forms of Power. Experiencing Contemporary Spaces of Resistance. Lidia Katia Consiglia Manzo, ed. Pp. 122-127. Champaign, IL: Common Gound.

Conquergood, Dwight

1989 Poetics, Play, Process, and Power: The Performative Turn in Anthropology. Text and Performance Quarterly, 9(1): 82-88.

Crinall, Karen

2015 Beyond Foucault's Subject of Power: Affect and Visual Emergence in Grass-Roots Social Activism. In Culture and Visual Forms of Power. Experiencing Contemporary Spaces of Resistance. Lidia Katia Consiglia Manzo, ed. Pp. 19-41. Champaign, IL: Common Ground Publishing.

Denzin, Norman K.

2003 Performance Ethnography. Thousand Oaks, CA: Sage Publications.

Denzin, Norman K., and Yvonna S. Lincoln (eds.)

1994 Handbook of Qualitative Research. Thousand Oaks, CA: Sage Publications.

Eco, Umberto

1984 The Role of the Reader: Explorations in the Semiotics of Texts. Bloomington: Indiana University Press.

Fine, Michelle

1994 Dis-Stance and Other Stances: Negotiations of Power inside Feminist Research. In Power and Methods. Andrew Gitlin, ed. Pp. 13-35. New York: Routledge.

Foucault, Michel

1983 The Subject and Power. In Michel Foucault: Beyond Structuralism and Hermeneutics. 2nd edn. Hubert L. Dreyfus and Paul Rabinow, eds. 4: 208-226. Chicago: University of Chicago Press.

Geertz, Clifford

1973 The Interpretation of Cultures. New York: Basic Books.

Gergen, Mary M., and Kenneth J. Gergen

2000 Qualitative Inquiry: Tensions and Transformations. In Handbook of Qualitative Research. Norman K. Denzin and Yvonna S. Lincoln, eds. Pp. 1025-1046. Thousand Oaks, CA: Sage Publications.

Harvey, David

1982 The Limits to Capital. Oxford: Blackwell.

2006 Spaces of Global Capitalism. London: Verso.

Lassiter, Luke Eric

2005 The Chicago Guide to Collaborative Ethnography. Chicago: University of Chicago Press.

MacDougall, David

2006 The Corporeal Image: Film, Ethnography, and the Senses. Princeton and Oxford: Princeton University Press. 
Madison, D. Soyini

2005 Critical Ethnography: Method, Ethics, and Performance. Thousand Oaks, CA: Sage Publications.

Mancini, Letizia, and Daniele Cologna

2000 Inserimento Socio-Economico e Percezione dei Diritti di Cittadinanza degli Immigrati Cinesi a Milano. Una Ricerca Pilota. Sociologia del Diritto, 3: 53-94.

Manzo, Lidia Katia C.

2011 The "Asian Betweeners." Cultural Identities and the New Communication Technologies. In Migration, Technology and Transculturation: A Global Perspective. Myna German and Padmini Banerjee, eds. Pp. 107-125. St. Charles, MO: Lindenwood University Press.

2012 Emergent Spaces, Contemporary Urban Conflicts. Experiences of Social Mix in Changing Neighborhoods: The Case Study Milan's Chinatown. In Living on the Boundaries: Urban Marginality in National and International Contexts. Carol Camp Yeakey, ed. Pp. 1-29. Bristol: Emerald.

2015 And Their Struggle Becomes Visible. For a Radical Revaluation of Foucault's Conception of Resistance to Power. In Culture and Visual Forms of Power. Experiencing Contemporary Spaces of Resistance. Lidia Katia Consiglia Manzo, ed. Pp. 1-10. Champaign, IL: Common Ground Publishing.

2016a (Foto)video Etnografia Collaborativa Negli Spazi Urbani. La Produzione Di "Aquila Bianca" Nell'ex-Italcementi Di Trento. In Metodi Visuali di Ricerca Sociale. Annalisa Frisina, ed. Pp. 191-210. Bologna: Il Mulino.

2016b Via Via, Vieni via Di Qui!" Il Processo Di Gentrificazione di via Paolo Sarpi, La Chinatown Di Milano (1980-2015). Archivio di Studi Urbani e Regionali, 117: 27-50.

Mitchell, Claudia

2011 Doing Visual Research. London: Sage Publications.

Nathansohn, Regev, and Dennis Zuev (eds.)

2013 Sociology of the Visual Sphere. New York: Routledge.

Novak, Christian

2002 Il Quartiere Cinese di Canonica Sarpi in Bilico fra Radicamento e Conflitto. In La Cina Sotto Casa. Convivenza e Conflitti tra Cinesi e Italiani in Due Quartieri di Milano. Daniele Cologna, ed. Pp. 19-26. Milano: Franco Angeli.

Panagia, Davide

2009 The Political Life of Sensation. Durham, NC, and London: Duke University Press.

Pink, Sarah

2007 Doing Visual Ethnography. 2nd edn. Thousand Oaks and London: Sage Publications.

2011 Images, Senses and Applications: Engaging Visual Anthropology. Visual Anthropology, 24(5): 437-454.

Rabiger, Michael

2009 Directing the Documentary. Burlington: Focal Press/Elsevier.

Rose, Gillian

2001 Visual Methodologies: An Introduction to the Interpretation of Visual Materials. London: Sage Publications.

Rothman, William (ed.)

2009 Three Documentary Filmmakers. Errol Morris, Ross McElwee, Jean Rouch. Albany: SUNY Press.

Sandercock, Leonie, and Giovanni Attili (eds.)

2010 Multimedia Explorations in Urban Policy and Planning: Beyond the Flatlands. London: Springer.

Sandercock, Leonie, and Giovanni Attili

2014 Changing the Lens: Film as Action Research and Therapeutic Planning Practice. Journal of Planning Education and Research, 34(1): 19-29.

Shortell, Timothy, and Konrad Aderer

2014 Drifting in Chinatowns: Toward a Situationist Analysis of Polyglot Urban Spaces in New York, Paris, and London. In Walking in the European City. Timothy Shortell and Evrick Brown, eds. Pp. 109-128. Farnham and Burlington: Ashgate.

Sikand, Nandini

2015 Filmed Ethnography or Ethnographic Film? Voice and Positionality in Ethnographic, Documentary, and Feminist Film. Journal of Film and Video, 67(3-4): 42-56. 
Smith, Neil

1996 The New Urban Frontier: Gentrification and the Revanchist City. London and New York: Routledge.

Strandvad, Sara Malou

2013 Symmetrical Ethnography: A Study of Filmmakers Portraying Academia. Visual Studies, 28(1): 38-51.

Verga, Pietro L.

2016 Rhetoric in the Representation of a Multi-Ethnic Neighbourhood: The Case of Via Padova, Milan. Antipode, 48(4): 1080-1101.

White, C. J., M. V. Makris, and S. Lizaire-Duff

2011 Listening to the City: Community Research with Newark's Historic James Street Commons Neighborhood. Cultural Studies $\longrightarrow$ Critical Methodologies, 11: 453-463. 